ISSN : 2548-6985

\title{
Perancangan Sistem Informasi Perpustakaan AMIK STIEKOM Sumatera Utara Berbasis Teknologi Radio Frekuensi Identification (RFID)
}

\author{
${ }^{1)}$ Sony Bahagia Sinaga \\ AMIK STIEKOM Sumatera Utara, JI. A.H Nasution No. 19, Sumatera Utara, Indonesia \\ http:// www.amikstiekomsu.ac.id, Email : sonybahagia@gmail.com \\ ${ }^{2)}$ Paska Marto Hasugian \\ STMIK Pelita Nusantara, Jl. Iskandar Muda No. 1 Medan, Sumatera Utara, Indonesia \\ http : // www.penusa.ac.id, Email : paskamarto86@gmail.com
}

\begin{abstract}
ABSTRAK
Penelitian ini memaparkan struktur data dalam merancang dan membangun sistem informasi perpustakaan AMIK STIEKOM Sumatera Utara menggunakan Radio Frequency Identification (RFID) berbasis client server. Penulis berharap agar para pembaca lebih memahami pemecahan masalah perparkiran yang lebih terpadu dan terdokumentasi dengan baik serta efisien dalam operasionalnya. Struktur data yang telah dirancang mampu mengidentifikasikan nomor peserta yang telah dilengkapi teknologi sistem perpustakaan Radio Frequency Identification (RFID). Mahasiswa/l yang meminjam maupun mengembalikan buku diseleksi melalui teknologi aplikasi sesuai dengan data mahasiswa/l yang terekam dalam database. Hanya data mahasiswa/l yang terdaftar dalam database saja yang dapat meminjam dan mengembalikan buku pada perpustakaan AMIK STIEKOM Sumatera Utara. Adapun untuk melakukan proses seleksi data pada sistem perpustakaan dengan teknologi RFID ini dilakukan dalam tiga tahapan, yaitu tahap perancangan logik, tahap perancangan fisik, dan tahap perancangan interface.
\end{abstract}

Kata Kunci : Sistem, Informasi, Perpustakaan, RFID, Client Server

\section{PENDAHULUAN}

Perkembangan teknologi informasi saat ini telah dirasakan dalam semua bidang kehidupan manusia. Teknologi telah banyak digunakan untuk memudahkan pekerjaan manusia, baik itu di kalangan perkantoran, dunia pendidikan, dunia usaha sampai pada kalangan ibu-ibu rumah tangga. Demikian juga dengan perkembangan teknologi di bidang sistem otomasi.

Perpustakaan merupakan suatu tempat menyimpan koleksi baik berupa buku, majalah dan koleksi lainnya yang dikelola oleh suatu institusi maupun kota. Perpustakaan dimanfaatkan oleh mahasiswa/l untuk meminjam koleksi tersebut. Perpustakaan diharapkan dapat membantu mahasiswa/l untuk meningkatkan minat baca, meningkatkan kemampuan berfikir dan mengembangkan ilmu pengetahuan .

Radio Frekuensi Identification (RFID) adalah teknologi identifikasi berbasis gelombang radio. RFID mampu mengidentifikasi berbagai objek secara simultan tanpa diperlukan kontak langsung (dalam jarak pendek). ${ }^{[1]}$ Perkembangan RFID merupakan pengganti atau penerus teknologi barcode. System RFID memiliki dua bagian yang terpenting yaitu RFID Tag dan RFID reader.

Dalam sirkulasi pengembalian buku pada perpustakaan AMIK STIEKOM Sumatera Utara memiliki banyak masalah yang timbul. Masalah yang sering terjadi adalah anggota perpustakaan sering lupa mengembalikan buku pada waktu yang telah ditentukan, dikarenakan keterbatasan jam operasional dari perpustakaan. Dengan terhentinya jam operasional perpustakaan maka anggota perpustakaan harus menunggu dan terkadang mendapatkan denda akibat keterbatasan keterbatasan jam operasional.

Adapun rumusan masalah yang akan dibahas dalam penelitian ini adalah :

1. Bagaimana merancang sistem informasi perpustakaan pada AMIK STIEKOM Sumatera Utara?

2. Bagaimana pemanfaatan teknologi RFID untuk dapat terintegritas dengan Sistem Informasi perpustakaan AMIK STIEKOM Sumatera Utara berbasis client server? Penelitian ini menghasilkan sebuah aplikasi yang efektif sesuai dengan kebutuhan seorang kepala perpustakaan. Adapun rincian urgensi dari penelitian ini adalah 1) Mempermudah pustakawan untuk pengelolaan administrasi di perpustakaan AMIK STIEKOM Sumatera Utara, 2)

Perancangan Sistem Informasi Perpustakaan AMIK STIEKOM Sumatera Utara Berbasis

Teknologi Radio Frekuensi Identification (RFID). Oleh : ${ }^{1)}$ Sony Bahagia Sinaga, ${ }^{2)}$ Paska M Hasugian 
ISSN : 2548-6985

Mempermudah pustakawan untuk mengetahui pengunjung perpustakaan AMIK STIEKOM Sumatera Utara dalam satu hari, 3) Mempermudah kepala perpustakaan dalam memonitor data perpustakaan dengan menggunakan Teknologi RFID berbasis client server.

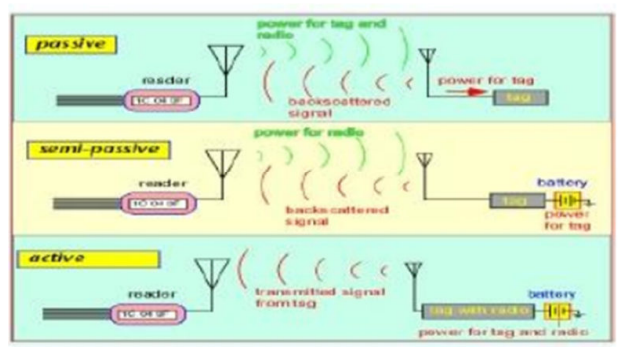

Gambar 1. RFID Tag dan Penggolongannya

Sistem informasi adalah suatu sistem didalam suatu organisasi yang mempertemukan kebutuhan pengolahan transaksi harian mendukung fungsi operasi organisasi yang bersifat manajerial dengan kegiatan strategi dari suatu organisasi untuk dapat menyediakan kepada pihak luar tertentu dengan laporan-laporan yang diperlukan. Sistem informasi dapat didefenisikan sebagai jaringan prosedur pengolahan data yang dikembangkan dalam suatu organisasi dan disatukan apabila dipandang perlu dangan maksud memberikan data pada manajemen setiap waktu diperlukan, baik data yang bersifat ekstern untuk dasar pengambilan keputusan dalam rangka mencapai tujuan organisasi. $^{[2]}$

Untuk memudahkan dan mengikuti langkah-langkah dalam pembuatan sistem harus membuat deskripsi tentang sistem yang dibuat. Deskripsi ini kemudian akan menjadi bahan diskusi antara perancang sistem dan pengguna sistem. Tujuan dari perancangan sistem ini adalah untuk merancang kebutuhan sistem yang diiginkan oleh pemakai serta membuat gambaran yang jelas. Langkahlangkah perancagan sistem adalah sebagai berikut :

a. Mengadakan survey untuk mengetahui kebutuhan pemakai.

b. Membuat deskripsi kebutuhan sistem.

c. Merancang desain yang mengimplementasikan model yang diinginkan pemakai.

d. Melakukan implementasi dengan mempresentasikan desain kedalam program.

e. Mengadakan uji coba, yaitu menguji seluruh spesifikasi yang terstruktur.

f. Melakukan instalasi, yaitu pemasangan perangkat sistem. ${ }^{[3]}$

Untuk mendeteksi data menggunakan teknologi RFID, data tersebut harus tersimpan didalam database. Model database menyatakan hubungan antar rekaman yang tersimpan dalam basis data. Beberapa literature menggunakan istilah struktur data logis. Untuk memodelkan database dapat dilihat sebagai berikut :

a. Model Data Hirarkis

Model data hirarkis biasa disebut model pohon, karena mirip pohon yang dibalik. Model ini menggunakan pola hubungan orangtua-anak.

b. Model Data Jaringan

Model ini distandarisasikan pada tahun 1971 oleh Database Task Group (DBTG). Itulah sebabnya disebut model DBTG. Model ini menyerupai model hirarkis, dengan perbedaan setiap simpul bisa memiliki lebih dari satu anak.

c. Model Relasional

Model Relasional adalah yang paling sederhana hingga mudah digunakan dan dipahami oleh pengguna, serta merupakan yang paling populer. Model ini menggunakan tabel berdimensi dua (yang disebut relasi atau tabel). ${ }^{[4]}$

\section{METODE PENELITIAN}

Pendekatan yang digunakan dalam penelitian ini adalah metode grounded teori (Grounded Theory Approach) yaitu metode penelitian kualitatif yang menggunakan sejumlah prosedur sistematis guna mengembangkan teori dari kancah. Pendekatan ini pertama kali disusun oleh dua orang sosiolog; Barney Glaser dan Anselm Strauss. Metode tersebut sesuai dengan kebutuhan akan aplikasi RFID berdasarkan struktur data dalam database yang berorientasi pada tindakan/interaksi, maka cocok digunakan untuk penelitian terhadap perilaku atau kajian aplikasi dengan objek bergerak. Penelitian ini tidak bertolak dari suatu teori atau untuk menguji teori (seperti paradigma penelitian kuantitatif), melainkan bertolak dari data menuju suatu teori.

Pendekatan Grounded Theory merupakan metode ilmiah, karena prosedur kerjanya yang dirancang secara cermat sehingga memenuhi keriteria metode ilmiah. Keriteria dimaksud adalah adanya signifikansi, kesesuaian antara teori dan observasi, dapat digeneralisasikan, dapat diteliti ulang, adanya ketepatan dan ketelitian, serta bisa dibuktikan.

Perancangan Sistem Informasi Perpustakaan AMIK STIEKOM Sumatera Utara Berbasis

Teknologi Radio Frekuensi Identification (RFID). Oleh : ${ }^{1}$ Sony Bahagia Sinaga, ${ }^{2)}$ Paska M Hasugian 
ISSN : 2548-6985

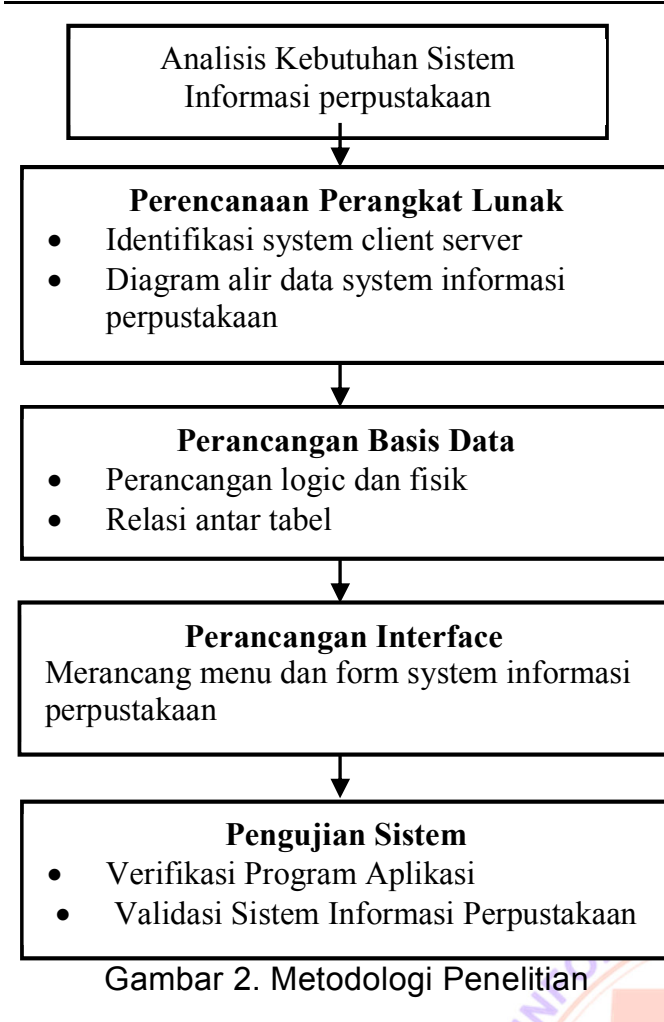

\section{ANALISA DAN PEMBAHASAN}

Kondisi Perpustakaan AMIK STIEKOM Sumatera Utara saat ini masih menggunakan pencatatan pada buku peminjaman dan pengembalian buku maka layanan di perpustakaan sedang banyak, maka proses ini akan membuat antrian orangorang yang ingin melakukan transaksi peminjaman ataupun pengembalian koleksi perpustakaan. Ini membuat waktu kerja petugas banyak terbuang hanya untuk melayani peminjaman dan pengembalian koleksi perpustakaan tanpa bisa menangani keamanan koleksi perpustakaan. Selain itu, juga mempunyai kapasitas penyimpanan data yang sangat terbatas dan tidak bisa diprogram ulang sehingga menyulitkan untuk menyimpan dan memperbaharui data dalam jumlah besar untuk sebuat item. Adapun gambar system yang sedang berjalan dapat dilihat pada gambar dibawah ini.

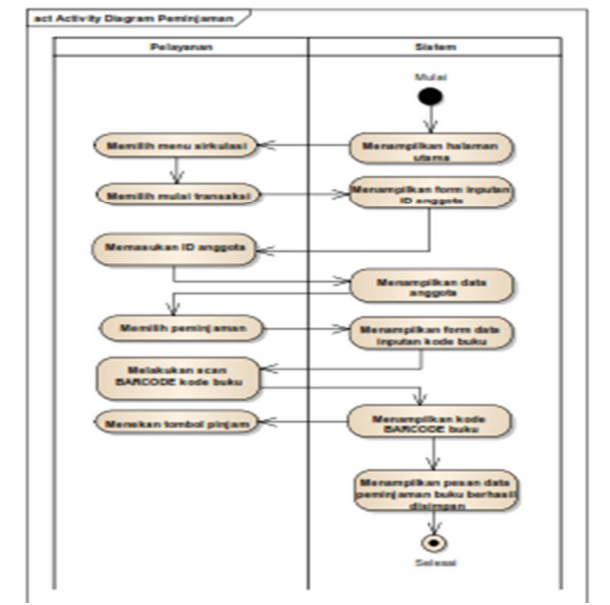

Gambar 3. Sistem yang Sedang Berjalan Peminjaman Buku

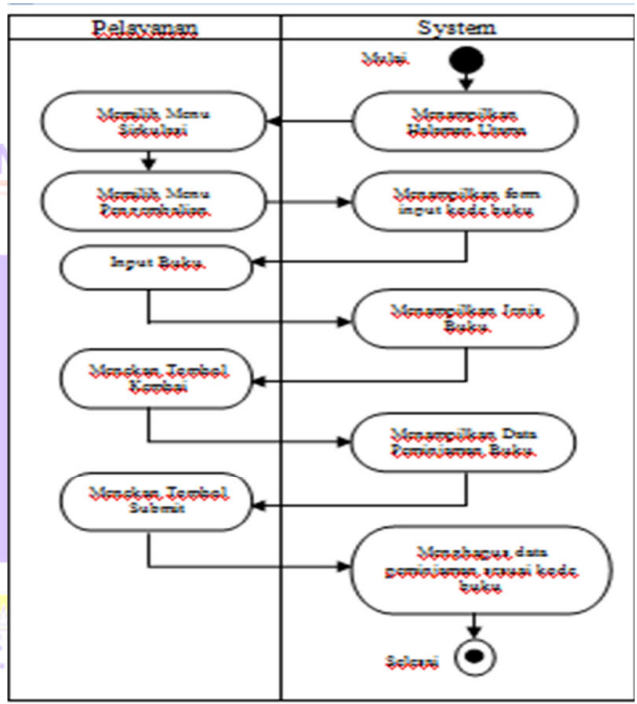

Gambar 4. Sistem Yang Sedang Berjalan Pengembalian Buku

Analisis Arsitektur Sistem merupakan proses untuk mendeskripsikan fisik sistem yang akan dibangun, komponen-komponen sistem yang akan dibangun meliputi :

1. Aplikasi Perpustakaan dilengkapi dengan Aplikasi RFID, berfungsi mengelola sirkulasi peminjaman dan pengembalian buku.

2. Mesin dan Aplikasi Pendaftaran dan Pengelolaan Anggota, berfungsi untuk mengelola data identitas anggota

3. Mesin Deteksi Pencurian (anti-theft), berfungsi sebagai kemananan koleksi yang terdapat di perpustakaan. 
ISSN : 2548-6985

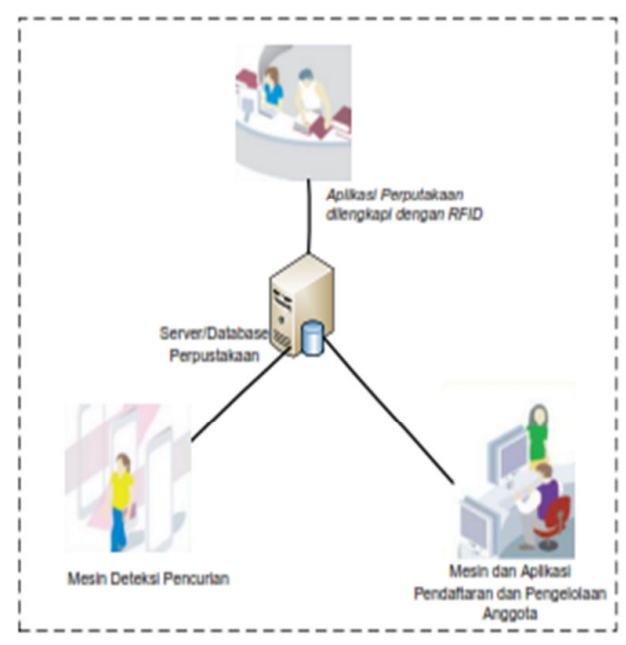

Gambar 5. Arsitektur Sistem

Integrasi merupakan proses untuk menghubungkan beberapa sistem-sistem komputerisasi dan software aplikasi baik secara fisik maupun secara fungsional. Integrasi Teknologi RFID pada Sistem Informasi Perpustakaan dapat dilihat pada flowchart gambar dibawah ini.

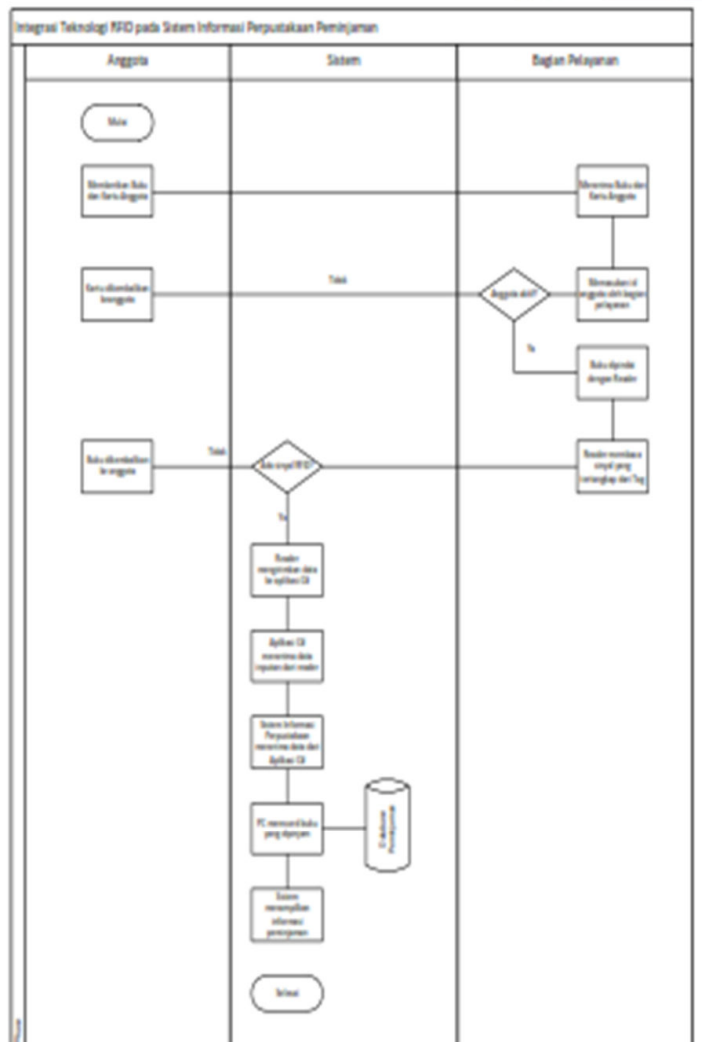

Gambar 6. Integritas RFID Peminjaman Buku

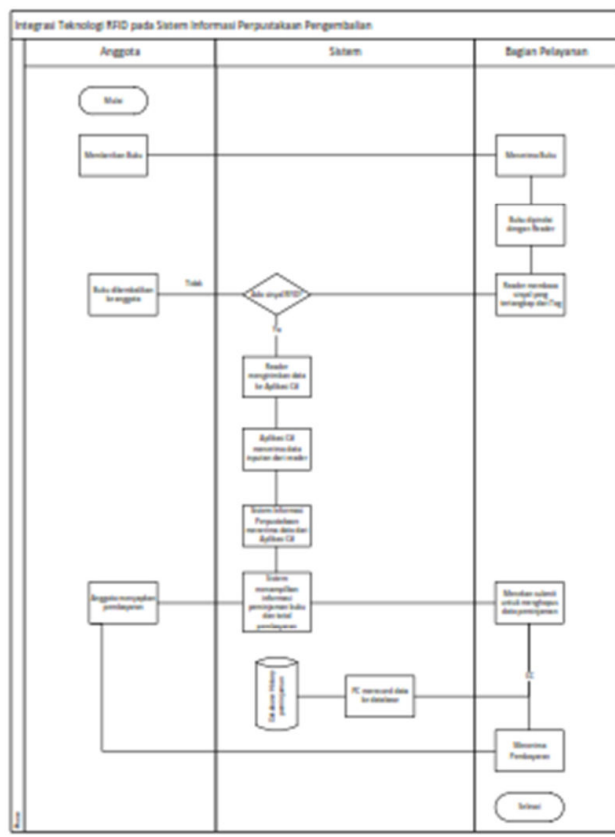

Gambar 7. Integritas RFID Pengembalian Buku

\section{HASIL DAN PEMBAHASAN}

Untuk melakukan proses seleksi data pada sistem informasi perpustakaan AMIK STIEKOM Sumatera Utara dengan teknologi RFID ini dilakukan dalam tiga tahapan, yaitu tahap perancangan logic, tahap perancangan fisik, dan tahap perancangan interface.

1. Pertama penelitian ini akan membuat dan membahas tahap perancangan logic (Logical Database Design).

2. Kedua penelitian ini akan membuat dan membahas tahap perancangan fisik (Physical Database Design).

3. Ketiga penelitian ini akan membuat dan membahas tahap perancangan interface.

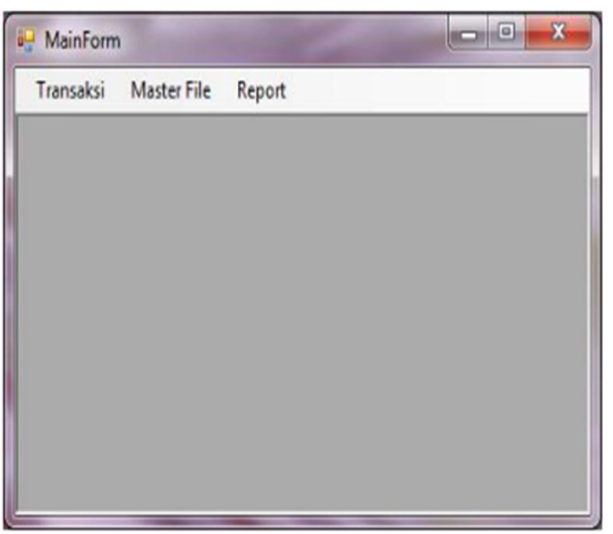

Gambar 8. Form Menu Utama 
ISSN : 2548-6985

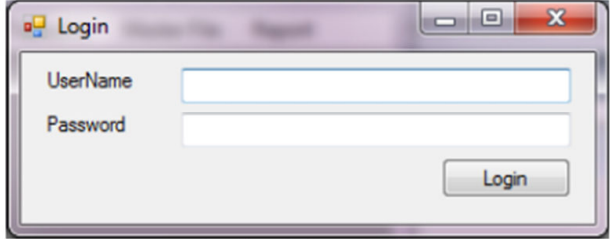

Gambar 9. Form Login

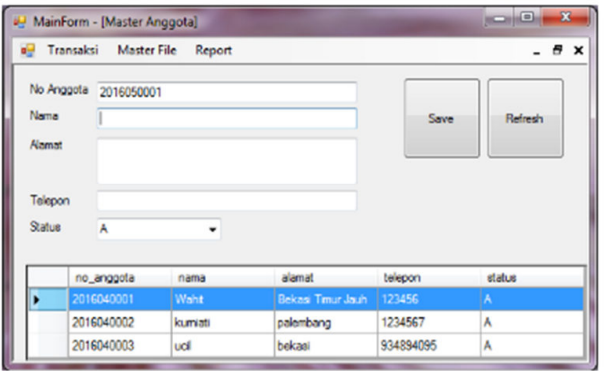

Gambar 10. Form Master Anggota

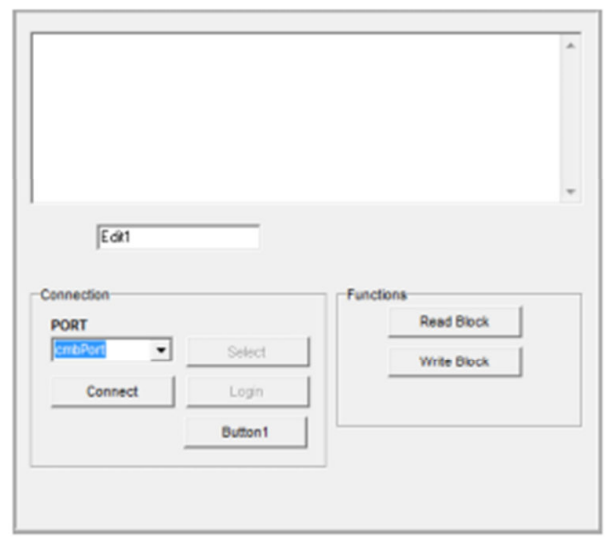

Gambar 11. Form Pengaturan RFID

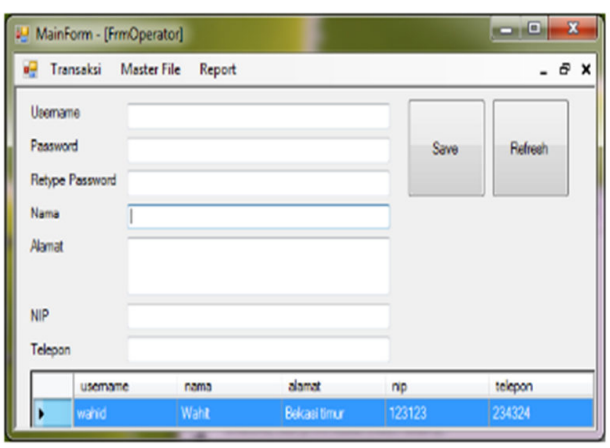

Gambar 12. Form Master Operator

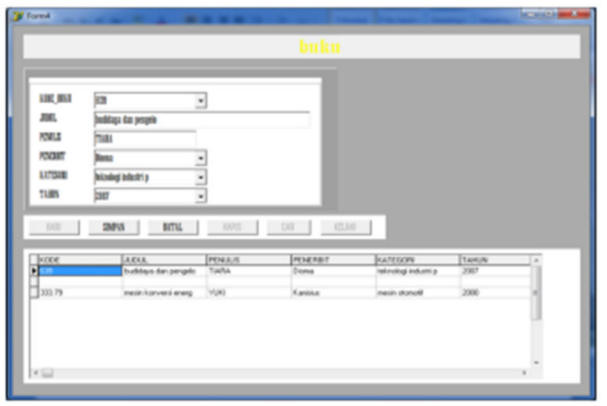

Gambar 13. Form Buku

\section{KESIMPULAN}

Adapun yang menjadi kesimpulan dalam penelitian ini adalah:

1. Berdasarkan dari hasil dan pembahasan mengenai sistem informasi Perpustakaan yang berbasis RFID dapat membantu kinerja staff dibagian perpustakaan, baik itu dalam proses pendaftaran anggota maupun proses transaksi peminjaman dan pengembalian buku di perpustakaan.

2. Proses transaksi peminjaman dan pengembalian buku yang ditunjang dengan adanya aplikasi perpustakaan dapat dilakukan lebih efisien, sehingga proses tersebut tidak akan memakan waktu yang lama dan memperkecil kemungkinan hilangnya data transaksi yang disebabkan oleh rusak atau hilangnya dokumen transaksi. Penyajian berbagai bentuk laporan dari bagian perpustakaan yang sudah dilakukan secara otomatis memudahkan dalam menyampaikan informasi.

\section{DAFTAR PUSTAKA}

1. Yana Yuniarsyah, dkk, Rancang Bangun Keanggotaan Perpustakaan STT Telematika Telkom Menggunakan RFID Berbasis Java 2 Standard Edition", 2013

2. Sutabri, Tata, Analisa Sistem Informasi, Yogyakarta, Penerbit : Andi, 2004.

3. Al-Bahra Bin Ladjamudin, Analisa dan Desain Sistem Informasi, Yogyakarta, Penerbit: Andi, 2005

4. Abdul Kadir \& Terra Ch. Triwahyuni, Pengenalan Teknologi Informasi, Yogyakarta, Penerbit : Andi, 2003.

5. Maryono, 2005, Dasar-Dasar Radio Frekuensi, Jurnal IImiah, Vol. XIV, Edisi 3. 